\title{
Microbiological Properties of Probioticated Kununzaki Drink Enriched with Cocoa Powder
}

\author{
H. A. Adeniran, D. M. Adeniyi and K. A. Taiwo
}

\begin{abstract}
Kununzaki- a popular and an affordable West African cereal-based beverage was enriched with cocoa powder and subjected to 'probiotication' with 'probiotic' lactic acid bacteria and subsequently investigated for sustained viability of the microbes and ability to suppress growth of food-borne bacteria. This study enumerated the different microbes in enriched kununzaki drink before and during storage, identified the isolated microbes and assessed the viability of the 'probiotic' lactic acid bacteria (LABs) in the drink and determined the antagonistic effect of the LABs on two selected food-borne pathogens. This was with a view to enhancing the health giving attributes of affordable kununzaki, which is already a popular beverage in Nigeria. Laboratory results revealed total viable bacteria, lactic acid bacteria and mould counts to range from 4.69 - 8.76, $6.45-9.74$ and $6.04-8.77 \log \mathrm{cfu} \mathrm{ml}^{-1}$, respectively. The microorganisms isolated were identified as: Bacillus brevis, $B$. Badius, B. polymyxa, B. macquariensis, B. pantothenticus, Staphylococcus aureus, S. epidermidis, Serratia marcescens, Lactobacillus delbrueckii, L. fermentum, L. plantarum, L. casei, Aspergillus niger, and Curvularia affinis. 'Probiotic' lactic acid bacteria were viable $\left(69.75 \log \mathrm{cfu} \mathrm{ml}^{-1}\right)$ at the end of four weeks of storage. The viabilities of Lactobacillus fermentum which were 9.75 and $9.58 \mathrm{log} \mathrm{cfu} \mathrm{ml}^{-1}$ at ambient and refrigerated temperatures, respectively were higher than those of other lactic acid bacteria species. The same organism was found to be active against one of the tested food-borne pathogens, Escherichia coli as evident in the diameter of zone of inhibition on plate and broth culture analyses. The study concluded that Lactobacillus fermentum could be effectively used for 'probiotication' of kununzaki enriched with $20 \%$ cocoa powder and the resulting product exhibited potential of checkmating a food-borne bacterial strain and by implication has the potential of promoting the health of consumers. The product was also found to be microbiologically stable for 4 weeks of storage at ambient and refrigeration temperatures.
\end{abstract}

Index terms - Kununzaki, probiotication, probiotic potential, viability.

\section{INTRODUCTION}

Kununzaki is a local fermented non-alcoholic cereal beverage in Nigeria and especially in Northern part of the country. It is, however, becoming widely consumed in the southern parts of Nigeria and some West African communities among low and middle income workers who cannot afford industrially produced beverages. Its popularity is due to its characteristic sweet-sour taste, refreshing quality as well as the

Published on November 9, 2020.

H. A. Adeniran, Department of Food Science and Technology, Obafemi Awolowo University, Ile-Ife, Nigeria.

(e-mail: hadeniran@oauife.edu.ng, hexadeniran@oauife.edu.ng)

D. M. Adeniyi, Department of Food Science and Technology, Obafemi Awolowo University, Ile-Ife, Nigeria. creamy or milky appearance and its flowing consistency. The beverage is millet- or sorghum-based food drink which is consumed within few hours of its production.

Traditional production of kununzaki is characterized by fermentation which is dependent on chance inoculation. The spontaneous fermentation coupled with the rudimentary equipment used in its production process results in products of inconsistent quality. The sanitary quality of the product during production is poor, thereby giving rise to products with short shelf-life [1] It is made by soaking the grains (sorghum or millet) in water for few days and grinding the soaked grains with ginger, cloves, pepper, depending on one's choice to form a smooth paste. Each of the ingredients is added for different reasons in the course of preparation [2]. Brief fermentation usually occurs during kununzaki processing. This occurs during steeping of the grains in water over 24 - 48hours period and is known to involve mainly lactic acid bacteria and yeasts. Substantial nutrient losses occur during various steps of kununzaki processing such as steeping, milling, and sieving [3]. Cocoa (Theobroma cacao) powder had been reported to have numerous health benefits. Polyphenol compounds present in cocoa powder significantly contribute to its health-promoting activities. Cocoa is rich in flavonoids, which have been documented to have health benefits. The flavonoids reduce the risk of cardiovascular disease by decreasing blood pressure and improving blood vessels functioning. Consuming foods that are high in flavonoids reduces inflammation and helps to prevent insulin resistance, which can decrease the risk of type 2 diabetes. The antioxidant capacity of fibre rich cocoa powder and its physico-chemical properties make it suitable to be used in the preparation of low-calorie, high-fibre food [4]. Modern nutritional probiotic products are classified as those that contain probiotic microorganisms. Probiotics are defined as non-toxic, non-pathogenic live microorganisms which when ingested, benefit the health of the host through their effect on some troublesome intestinal microflora [5]. For this this function to be performed, probiotic cultures must be able to survive throughout the intestinal tract, resist acidic conditions during gastric passage and bile digestion [6]. To have their beneficial effect on the health of the host, probiotic strains must be able to adapt, and survive among the natural microflora of the intestine [5], [7]. To date, strains and species of

(e-mail: mercyadeniyi8@gmail.com)

K. A. Taiwo, Department of Food Science and Technology, Obafemi Awolowo University, Ile-Ife, Nigeria. 
Lactobacilli, Bifidobacteria, Enterococci and Lactococci are mostly employed for as probiotics in food [8]. Consumption of probiotics has been reported to be helpful in maintaining good health, restore body vigor and combat intestinal disorders through the therapeutic and beneficial effects associated with them [5]. Probiotics are conventionally added to dairy products like yogurt, dahi and other fermented dairy food [9] and thereby raising them to the status of functional foods. However, the increasing health concerns of lactose intolerance, milk protein allergy, high-cholesterol content and high amounts of saturated fatty acids of dairy-based foods are resulting in a shift of interest towards non-dairy for odds such as probiotic fermented cereals, fruits and vegetables juices [10], [11].

Non-dairy based probiotic foods are now finding their way into human routine life one after the other. Roselle extract, ginger drink, blends of tigernut milk, soymilk and groundnut, soymilk, African yam bean based drink, and have been reported on as veritable carriers of LABs and Bifidobacteria with probiotic potentials [12]-[14].

[15] reported on the physico-chemical and proximate compositions of kununzaki drink enriched with cocoa powder. The present study provides information on the microbiological characteristics, viability of LAB strains with probiotic potential in kununzaki enriched with cocoa powder, antagonistic effect of the 'probiotic' fermented milk anlogue on two selected foodborne pathogens.

\section{MATERIALS AND METHODS}

\section{A. Production of Kununzaki}

The method of [17] with the recipe in Table 1 and flowchart in Fig. 1 was employed for production of kununzaki. Twelve grams (12 g) of cocoa powder was dissolved in $240 \mathrm{ml}$ of water to produce cocoa slurry using the method of [18]. To Prepare $500 \mathrm{ml}$ of $80 \%$ Sorghum based Kununzaki and 20\% cocoa powder, one hundred millimeter $(100 \mathrm{ml})$ of the cocoa slurry prepared using the method of [19] as described above was taken to be $20 \%$ cocoa powder, this was added to $400 \mathrm{ml}$ of the Sorghum based kununzaki drink. The product (kununzaki) of equal quantities was packaged in sterile plastic bottles and pasteurized at $60{ }^{\circ} \mathrm{C}$ for 30 minutes, cooled and stored at ambient and refrigerated $\left(4 \pm 1{ }^{\circ} \mathrm{C}\right)$ conditions for four weeks. Microbiological analyses were carried out on the drinks before, during and after storage for four weeks.

The three different samples of Kununzaki drinks prepared were:

1. pasteurized $100 \%$ Sorghum based Kununzaki -KNC.

2. pasteurized $80 \%$ Sorghum based Kununzaki and 20\% cocoa powder - KPWC.

3. unpasteurized $80 \%$ Sorghum based Kununzaki and $20 \%$ cocoa powder - KUPC.

While the control, which was the millet based commercial Kununzaki - KCC was purchased and pasteurized using the same temperature and exposure time used for the laboratory samples.

\section{Sorghum grains}

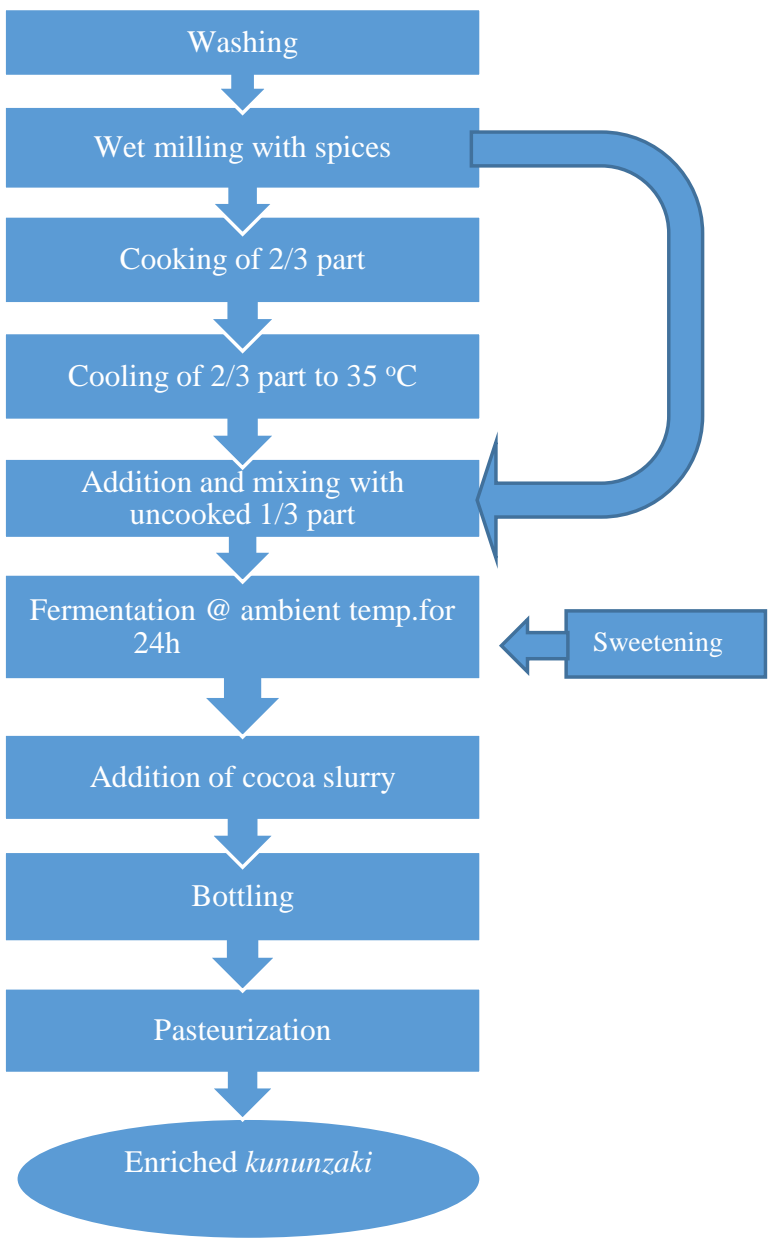

Fig 1. Modified process flow chart for the production of enriched kununzaki drink.

TABLE 1: RECIPE FOR THE PRODUCTION OF KUNUNZAKI ENRICHED DRINK

\begin{tabular}{ccc}
\hline $\begin{array}{c}\text { Ingredients and } \\
\text { mass(g) }\end{array}$ & Kununzaki & $\begin{array}{c}\text { Kununzaki } \\
\text { (Enriched) }\end{array}$ \\
\hline Sorghum & 500 & 500 \\
Cloves & 0.5 & 0.5 \\
Ginger & 6.5 & 6.5 \\
Black pepper & 0.5 & 0.5 \\
Red pepper & 2.5 & 2.5 \\
Sugar & 50 & 50 \\
Cocoa powder & - & 12 \\
\hline
\end{tabular}

Source: [16], [19] \& [20].

\section{B. Enumeration of Microorganisms from Kununzaki Samples}

Lactic acid bacteria, total viable bacteria, yeasts and moulds in kununzaki samples were enumerated using the methods of [13], [20], [21]. Following serial dilution of each sample, appropriate volume of the diluted sample was plated and incubated for 24-48 h for lab and total bacteria counts while 3 $d$ incubation period was employed for yeasts and mould counts. After incubation, the visible colonies on each plate were 
counted with a colony counter and the number of visible colonies multiplied by the reciprocal of the dilution factor.

\section{Identification of the Bacterial Isolates}

The bacteria isolates were characterized and identified following the methods of [20], [21]. Gram staining, spore staining test, oxidase test, catalase test, coagulase test, fermentation of selected sugars, nitrate reduction, production of ammonia from arginine in MRS broth, starch hydrolysis, growth in $4,6.5$, and $7.5 \% \mathrm{NaCl}$, growth at 15 and $45{ }^{\circ} \mathrm{C}$, methyl red test, Voges-Proskaeur test, Indole production, citrate utilization, growth at various temperatures $(50,55$ and $60{ }^{\circ} \mathrm{C}$ ), and gelatin liquefaction.

\section{Identification of Moulds}

Cultural observation: The pure cultures of the fungal isolates were identified based on the cultural and slide cultures were prepared and after $72 \mathrm{~h}$, fungal cultures were mounted on a microscope and observed with X10 and X40 objective lenses respectively. Species encountered were identified with standard mycological identification keys [22].

\section{E. Antimicrobial Screening of Isolates}

Antagonistic activity of the LABs isolates was carried out using agar well diffusion test [23]. Two food-borne bacterial strains, Staphylococcus aureus (NCIB 8585) and Escherichia coli (NCIB 86) were employed for the test. The LAB strains were cultured in MRS broth at $37^{\circ} \mathrm{C}$ for $24 h$. Wells were cut with a sterile cork borer ( $8 \mathrm{~mm}$ in diameter) in Mueller Hinton Agar media plates. The well was separately seeded with overnight culture of Staphylococcus aureus and Escherichia coli, and then inoculated with $0.03 \mathrm{ml}(\mathrm{v} / \mathrm{v})$ of an overnight broth culture of the LAB isolates. The plates were incubated for $24 \mathrm{~h}$ again and the appearance of inhibitory zones were observed and measured as antimicrobial activity of the LAB isolates against the selected food-borne pathogens.

\section{F. Viability of LAB and Food Borne Pathogens in Enriched Kununzaki Samples Stored at Ambient and Refrigeration Temperatures}

The three LAB strains with the highest zone of inhibition against food pathogens were assessed for viability and antagonistic properties on the food-borne pathogens in the sterilized, kununzaki drink samples. Introduction of LAB strains to enriched Kununzaki was carried out following the method of [13]. Overnight culture of LAB isolate was suspended in sterile distilled water; the cell suspension was then standardized to contain $10^{5}$ cells $\mathrm{ml}^{-1}$. In set A: one $\mathrm{ml}$ of $24 \mathrm{~h}$ old, standardized Staphylococcus aureus and each LAB strain were inoculated into $100 \mathrm{ml}(\mathrm{v} / \mathrm{v})$ of sterilized enriched Kununzaki samples. During storage at ambient and refrigeration temperatures for 28 days, weekly counts of Staphylococcus aureus was determined on Mannitol salt agar. Serially diluted samples were pour-plated, incubated at $35 \pm 2^{\circ} \mathrm{C}$ for $24 \mathrm{~h}$, afterwhich distinct colonies with yellow colour were recorded as Staphylococcus aureus. The second set contains one $\mathrm{ml}$ each of $24 \mathrm{~h}$ old, standardized Escherichia coli and LAB strain inoculated into $100 \mathrm{ml}$ sterile kununzaki drink, and organism enumerated as the first set. However, Eosin Methylene Blue Agar (EMBA) was employed. Dark colonies with green metallic sheen were recorded as Escherichia coli colonies. Three sets of control, one with just sterilized enriched Kununzaki (without any organism), and second with only Staphylococcus aureus while the third set was inoculated with only Escherichia coli only.

\section{G. Statistical Analysis}

Counts were subjected to analysis of variance (ANOVA) and the means were separated by Duncan's multiple range test (SPSS, version 23). Level of significance was determined at $5 \%$ level.

\section{RESUltS AND DISCUSSION}

A. Total Viable Bacteria Counts in Enriched Kununzaki Drink Samples at Ambient and Refrigeration Temperatures

Table 2 reveals that, during the storage period, total viable bacteria counts of all the laboratory samples ranged from 4.678.76 while pasteurized commercial millet-based Kununzaki had counts that ranged from 6.74-7.53 (log cfu $\left.\mathrm{ml}^{-1}\right)$. The highest being for KNC (pasteurized 100\% Sorghum-based Kununzaki stored at ambient temperature for one week while the lowest was for the same sample before storage (at week 0). For all the samples, the total viable counts increased significantly $(\mathrm{p}<0.05)$ from week 0 to week 1 at ambient and refrigeration temperatures. Subsequently, a decrease occurred from week 1 to 2 and stability was maintained from weeks 2 to 4. This trend was observed for both refrigeration and ambient temperatures. Apparently, the inclusion of $20 \%$ cocoa had no adverse effect on the microbiological stability of the samples. As no significant deviation in total microbial load was recorded for all the samples treated with the cocoa powder as against those not treated with cocoa powder. The increases in total viable counts from week 0 to 1 may be due to multiplication of microorganisms that survived the pasteurization and the fact that nutrients that could serve as substrates were available in the kununzaki. The organisms could have had their way into the drink through contaminated syrup, fermentation vessels, storage containers, sieves used for filtration, hands of the handlers and the polythene bags or bottles in which it is packaged for sale [25]. This high load of bacteria may cause short shelf life [26]. After week 1, biological stability was observed. Decrease in the $\mathrm{pH}$ of the samples, accumulation of metabolites and unfavourable environmental condition that was inimical for their growth likely resulted in this seeming stability. This trend agrees with the report of [27]. Generally, total viable counts were higher in all the samples stored at ambient temperature compared to those under refrigeration temperatures. Effect of lowered temperature on enzymecatalyzed biochemical reactions could be the reason for this observation. 
TABLE 2: TOTAL Viable BACTERIA COUNT (CFU ML -1) OF ENRICHED KUNUNZAKI DRINK SAMPLES AT AMBIENT AND REFRIGERATION TEMPERATURES

\begin{tabular}{cccccc}
\hline \hline \multirow{2}{*}{ Sample } & \multicolumn{5}{c}{ Storage Period (Week) } \\
\cline { 2 - 6 } & $\mathbf{0}$ & $\mathbf{1}$ & $\mathbf{2}$ & $\mathbf{3}$ & $\mathbf{4}$ \\
\hline KNC & $4.67 \pm$ & $8.76 \pm$ & $6.69 \pm$ & $6.20 \pm$ & $6.08 \pm$ \\
(Ambient) & $0.27^{\mathrm{c}}$ & $0.47^{\mathrm{a}}$ & $0.36^{\mathrm{b}}$ & $0.41^{\mathrm{b}}$ & $0.38^{\mathrm{b}}$ \\
KUPC & $4.86 \pm$ & $7.97 \pm$ & $7.00 \pm$ & $6.37 \pm$ & $6.15 \pm$ \\
(Ambient) & $0.36^{\mathrm{c}}$ & $0.55^{\mathrm{a}}$ & $0.35^{\mathrm{b}}$ & $0.30^{\mathrm{b}}$ & $0.36^{\mathrm{b}}$ \\
KPWC & $4.79 \pm$ & $7.98 \pm$ & $6.60 \pm$ & 6.20 & $6.03 \pm$ \\
(Ambient) & $0.22^{\mathrm{c}}$ & $0.31^{\mathrm{a}}$ & $0.43^{\mathrm{b}}$ & $\pm 0.38^{\mathrm{b}}$ & $0.41^{\mathrm{b}}$ \\
KCC & $6.74 \pm$ & $7.53 \pm$ & $6.77 \pm$ & $6.26 \pm$ & $6.10 \pm$ \\
(Ambient) & $0.41^{\mathrm{b}}$ & $0.21^{\mathrm{a}}$ & $0.44^{\mathrm{b}}$ & $0.36^{\mathrm{b}}$ & $0.28^{\mathrm{bc}}$ \\
KNC (Ref.) & $4.89 \pm$ & $8.53 \pm$ & $6.48 \pm$ & 6.15 & $6.06 \pm$ \\
& $0.27^{\mathrm{c}}$ & $0.49^{\mathrm{a}}$ & $0.36^{\mathrm{b}}$ & $\pm 0.34^{\mathrm{b}}$ & $0.26^{\mathrm{b}}$ \\
KUPC & $4.79 \pm$ & $7.19 \pm$ & 6.56 & 6.32 & 6.15 \\
(Ref.) & $0.36^{\mathrm{c}}$ & $0.52^{\mathrm{a}}$ & $\pm 0.36^{\mathrm{b}}$ & $\pm 0.35^{\mathrm{b}}$ & $\pm 0.23^{\mathrm{b}}$ \\
KPWC & $4.89 \pm$ & $8.05 \pm$ & $6.50 \pm$ & $6.18 \pm$ & $6.04 \pm$ \\
(Ref.) & $0.22^{\mathrm{d}}$ & $0.07^{\mathrm{a}}$ & $0.40^{\mathrm{b}}$ & $0.38^{\mathrm{c}}$ & $0.24^{\mathrm{c}}$ \\
& & & & \\
KCC (Ref.) & $6.74 \pm$ & $7.13 \pm$ & $6.54 \pm$ & $6.21 \pm$ & $6.08 \pm$ \\
& $0.41^{\mathrm{a}}$ & $0.07^{\mathrm{a}}$ & $0.47^{\mathrm{a}}$ & $0.42^{\mathrm{b}}$ & $0.20^{\mathrm{b}}$ \\
\hline \hline
\end{tabular}

Values with different superscript within row are significantly different $\mathrm{p}<0.05$.

Key: $\mathrm{KNC}=$ pasteurized $100 \%$ Sorghum-based Kununzaki, KUPC = unpasteurized $80 \%$ Sorghum-based Kununzaki and 20\% cocoa powder, KPWC = pasteurized $80 \%$ Sorghum-based Kununzaki and 20\% cocoa powder, KCC = pasteurized commercial Millet-based Kununzaki.

\section{B. Lactic Acid Bacteria Counts in Enriched Kununzaki Drink at Ambient and Refrigeration Temperatures}

The lactic acid bacteria count during storage ranged from 5.85 to $9.74\left(\log \mathrm{cfu} \mathrm{ml}^{-1}\right)$ (Table 3). Generally, there was a significant decrease $(\mathrm{p}<0.05)$ in lactic acid bacteria in kununzaki samples. In this study, LAB counts in all the samples were observed to be within the acceptable limit for probiotic products $(6-8 \log \mathrm{cfu} / \mathrm{ml})$ after 21 days of storage. However, reduction in LAB count from week 3 onward may be as a result of acidification of kununzaki coupled with production of metabolites which likely had inhibitory effect on microbial growth in kununzaki as reported by [17], [29]. Also, storage temperature influenced the result of LAB counts of kununzaki samples stored at ambient temperature, as some were generally higher than Kununzaki samples stored at refrigeration temperature during the storage. There was no significant difference ( $p>0.05)$ in the LAB counts of pasteurized $100 \%$ sorghum-based Kununzaki drink stored at ambient temperature at week 0 but decreased with increasing period of storage. Studies by [28], [29] revealed that LABs were the predominant microorganisms involved in the fermentation of starchy products.

\section{Mould counts in Enriched Kununzaki Drink at Ambient and Refrigeration Temperatures}

The mould counts of all the samples during the storage were between 6.04 and $8.77\left(\log \mathrm{sfu} \mathrm{ml}^{-1}\right)$ (Table 4). Mould counts of all samples stored at ambient and refrigeration temperature decreased significantly $(p<0.05)$ from week 0 to week 4 . The presence of moulds at the initial stage of fermentation and the subsequent reduction had been reported previously [30]. Fungi have role in the initial phase of fermentation mostly in saccharification of the predominantly starchy substrate [31].
Pasteurized commercial millet-based Kununzaki samples stored at ambient and refrigeration temperatures exhibited the highest mould count at week $0\left(8.37 \mathrm{log} \mathrm{sfu} \mathrm{m}^{-1}\right)$ which may be as a result of contamination by fungal spores from handling and the environment because most of the commercial Kununzaki are produced at home in an open environment using house utensils which are not usually sterile [25], however, at week 4 of storage, unpasteurized $80 \%$ sorghum-based Kununzaki sample stored at ambient temperature had highest mould count $\left(6.74 \log \mathrm{sfu} \mathrm{ml}^{-1}\right)$. On the influence of storage temperature at week 4, mould counts of Kununzaki samples stored at refrigeration temperature were lower than Kununzaki samples stored at ambient temperature probably because of lower metabolic rate of microbes at low temperatures.

TABLE 3: LACTIC ACID BACTERIA COUNTS LOG CFU ML -1) OF ENRICHED KUNUNZAKI DRINKS AT AMBIENT AND REFRIGERATION TEMPERATURES

\begin{tabular}{|c|c|c|c|c|c|}
\hline \multirow{2}{*}{ Sample } & \multicolumn{5}{|c|}{ Storage Period (Week) } \\
\hline & 0 & 1 & 2 & 3 & 4 \\
\hline KNC (Ambient) & $\begin{array}{c}7.66 \pm \\
0.35^{\mathrm{b}}\end{array}$ & $\begin{array}{l}7.95 \pm \\
0.18^{\mathrm{b}}\end{array}$ & $\begin{array}{c}9.74 \pm \\
0.42^{\mathrm{a}}\end{array}$ & $\begin{array}{l}7.63 \pm \\
0.37^{\mathrm{c}}\end{array}$ & $\begin{array}{c}7.72 \pm \\
0.35^{\mathrm{c}}\end{array}$ \\
\hline $\begin{array}{c}\text { KUPC } \\
\text { (Ambient) }\end{array}$ & $\begin{array}{c}9.70 \pm \\
0.43^{\mathrm{a}}\end{array}$ & $\begin{array}{l}8.51 \pm \\
0.26^{\mathrm{b}}\end{array}$ & $\begin{array}{c}8.41 \pm \\
0.01^{\mathrm{b}}\end{array}$ & $\begin{array}{c}7.67 \pm \\
0.31^{\mathrm{c}}\end{array}$ & $\begin{array}{c}7.55 \pm \\
0.39^{\mathrm{c}}\end{array}$ \\
\hline $\begin{array}{l}\text { KPWC } \\
\text { (Ambient) }\end{array}$ & $\begin{array}{c}8.05 \pm \\
0.22^{\mathrm{a}}\end{array}$ & $\begin{array}{c}8.02 \pm \\
0.09^{\mathrm{a}}\end{array}$ & $\begin{array}{c}8.51 \pm \\
0.50^{\mathrm{a}}\end{array}$ & $\begin{array}{l}7.70 \pm \\
0.33^{\mathrm{b}}\end{array}$ & $\begin{array}{l}7.63 \pm \\
0.37^{\mathrm{b}}\end{array}$ \\
\hline KCC (Ambient) & $\begin{array}{c}8.25 \pm \\
0.21^{\mathrm{a}}\end{array}$ & $\begin{array}{c}8.66 \pm \\
0.26^{\mathrm{a}}\end{array}$ & $\begin{array}{c}8.55 \pm \\
0.21^{\mathrm{a}}\end{array}$ & $\begin{array}{c}7.74 \pm \\
0.38^{\mathrm{b}}\end{array}$ & $\begin{array}{l}6.67 \pm \\
0.29^{c}\end{array}$ \\
\hline KNC (Ref.) & $\begin{array}{c}7.66 \pm \\
0.35^{\mathrm{a}}\end{array}$ & $\begin{array}{c}7.58 \pm \\
0.82^{\mathrm{a}}\end{array}$ & $\begin{array}{l}6.11 \pm \\
0.47^{\mathrm{b}}\end{array}$ & $\begin{array}{l}6.55 \pm \\
0.48^{\mathrm{b}}\end{array}$ & $\begin{array}{l}6.45 \pm \\
0.50^{\mathrm{b}}\end{array}$ \\
\hline KUPC (Ref.) & $\begin{array}{c}9.70 \pm \\
0.43^{\mathrm{a}}\end{array}$ & $\begin{array}{l}8.22 \pm \\
0.08^{\mathrm{b}}\end{array}$ & $\begin{array}{l}6.41 \pm \\
0.22^{\mathrm{d}}\end{array}$ & $\begin{array}{l}7.60 \pm \\
0.42^{c}\end{array}$ & $\begin{array}{l}7.52 \pm \\
0.40^{c}\end{array}$ \\
\hline KPWC (Ref.) & $\begin{array}{c}8.05 \pm \\
0.22^{\mathrm{a}}\end{array}$ & $\begin{array}{l}7.54 \pm \\
0.09^{\mathrm{b}}\end{array}$ & $\begin{array}{l}7.42 \pm \\
0.49^{\mathrm{b}}\end{array}$ & $\begin{array}{l}7.62 \pm \\
0.45^{\mathrm{b}}\end{array}$ & $\begin{array}{c}6.79 \pm \\
0.40^{c}\end{array}$ \\
\hline KCC (Ref.) & $\begin{array}{c}8.25 \pm \\
0.21^{\mathrm{a}}\end{array}$ & $\begin{array}{c}8.46 \pm \\
0.20^{\mathrm{a}} \\
\end{array}$ & $\begin{array}{l}7.72 \pm \\
0.47^{\mathrm{ab}} \\
\end{array}$ & $\begin{array}{l}7.54 \pm \\
0.42^{\text {ab }} \\
\end{array}$ & $\begin{array}{c}6.65 \pm \\
0.39^{\mathrm{b}} \\
\end{array}$ \\
\hline
\end{tabular}

Values with different superscript within row are significantly different at $\mathrm{p}<0.05$.

Key: $\mathrm{KNC}=$ pasteurized $100 \%$ Sorghum-based Kununzaki, KUPC=unpasteurized $80 \%$ Sorghum-based Kununzaki and 20\% cocoa powder, KPWC $=$ pasteurized $80 \%$ Sorghum-based Kununzaki and 20\% cocoa powder, $\mathrm{KCC}=$ pasteurized commercial Millet-based Kununzaki.

TABLE 4: Total MOULd COUNT (LOG SFu ML -1) IN ENRICHED KUNUNZAKI DRINK AT AMBIENT AND REFRIGERATION TEMPERATURES

\begin{tabular}{cccccc}
\hline \multirow{2}{*}{ Sample } & \multicolumn{5}{c}{ Storage Period (Week) } \\
\cline { 2 - 6 } & $\mathbf{0}$ & $\mathbf{1}$ & $\mathbf{2}$ & $\mathbf{3}$ & $\mathbf{4}$ \\
\hline \hline KNC & $7.34 \pm$ & $8.67 \pm$ & $8.48 \pm$ & $6.71 \pm$ & $6.73 \pm$ \\
(Ambient) & $0.42^{\mathrm{b}}$ & $0.42^{\mathrm{a}}$ & $0.47^{\mathrm{a}}$ & $0.43^{\mathrm{c}}$ & $0.41^{\mathrm{c}}$ \\
KUPC & $8.75 \pm$ & $8.77 \pm$ & $8.07 \pm$ & $6.70 \pm$ & $6.74 \pm$ \\
(Ambient) & $0.39^{\mathrm{a}}$ & $0.51^{\mathrm{a}}$ & $0.27^{\mathrm{b}}$ & $0.38^{\mathrm{c}}$ & $0.43^{\mathrm{c}}$ \\
KPWC & $8.66 \pm$ & $7.13 \pm$ & $7.90 \pm$ & $6.22 \pm$ & $6.31 \pm$ \\
(Ambient) & $0.34^{\mathrm{a}}$ & $0.40^{\mathrm{b}}$ & $0.25^{\mathrm{a}}$ & $0.35^{\mathrm{c}}$ & $0.40^{\mathrm{c}}$ \\
KCC & $8.37 \pm$ & $7.70 \pm$ & $8.38 \pm$ & $6.70 \pm$ & $6.49 \pm$ \\
(Ambient) & $0.49^{\mathrm{a}}$ & $0.44^{\mathrm{ab}}$ & $0.40^{\mathrm{a}}$ & $0.33^{\mathrm{c}}$ & $0.40^{\mathrm{c}}$ \\
KNC (Ref.) & $7.34 \pm$ & $7.30 \pm$ & $8.30 \pm$ & $6.17 \pm$ & $6.35 \pm$ \\
& $0.42^{\mathrm{b}}$ & $0.43^{\mathrm{b}}$ & $0.41^{\mathrm{a}}$ & $0.25^{\mathrm{c}}$ & $0.48^{\mathrm{c}}$ \\
KUPC (Ref.) & $8.75 \pm$ & $8.33 \pm$ & $7.85 \pm$ & $6.25 \pm$ & $6.54 \pm$ \\
& $0.39^{\mathrm{a}}$ & $0.35^{\mathrm{ab}}$ & $0.32^{\mathrm{b}}$ & $0.34^{\mathrm{c}}$ & $0.35^{\mathrm{c}}$ \\
KPWC (Ref.) & $8.66 \pm$ & $6.77 \pm$ & $7.90 \pm$ & $6.04 \pm$ & $6.16 \pm$ \\
& $0.34^{\mathrm{a}}$ & $0.01^{\mathrm{b}}$ & $0.35^{\mathrm{a}}$ & $0.23^{\mathrm{c}}$ & $0.26^{\mathrm{c}}$ \\
KCC (Ref.) & $8.37 \pm$ & $8.68 \pm$ & $8.10 \pm$ & $6.63 \pm$ & $6.34 \pm$ \\
& $0.49^{\mathrm{ab}}$ & $0.50^{\mathrm{a}}$ & $0.37^{\mathrm{b}}$ & $0.34^{\mathrm{c}}$ & $0.33^{\mathrm{c}}$ \\
\hline \hline
\end{tabular}

Values with different superscript within row are significantly different at $\mathrm{p}<$ 0.05 .

Key: $\mathrm{KNC}=$ pasteurized $100 \%$ Sorghum-based Kununzaki, KUPC = unpasteurized $80 \%$ Sorghum-based Kununzaki and 20\% cocoa powder, KPWC $=$ pasteurized $80 \%$ Sorghum-based Kununzaki and 20\% cocoa powder, $\mathrm{KCC}=$ pasteurized commercial Millet-based Kununzaki. 
D. Identification of Microorganisms Isolated from Enriched Kununzaki Drink Samples

Identification of the bacteria isolates from enriched kununzaki samples was based on morphological and biochemical characteristics. The Identification of fungal isolates was based majorly on morphological characteristics.

1. Identities of Non-Lactic Acid Bacteria Isolated from Enriched Kununzaki Drink

Table 5 shows the identities of the non-lactic acid bacterial isoaltes on the basis of morphological and biochemical characteristics as Bacillus brevis $s_{(\mathrm{a})}$, Bacillus badius, $B$. brevis $_{(\mathrm{b})}$, B. polymyxa, B. macquariensis $(\mathrm{a})$, Staphylococcus aureus, S. epidermidis, B. pantothenticus, Serratia marcescens,

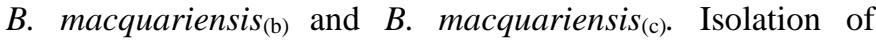
Bacillus spp., Staphylococcus and Enterobacteria have been reported to be present in Kununzaki drink by [25], [29], [32]. The presence of Staphylococcus sp could be a matter of public health concern as they have been implicated in causing food borne illness [32]. Staphylococcus sp. are usually found as normal flora of the skin, nose, throat, palms, hair and mucus membrane and a common etiological agent of septic arthritis [29]. [1] reported the presence of organisms like Bacillus cereus and Staphylococcus aureus in Kununzaki.

\section{E. Identities of Lactic Acid Bacteria Isolates}

Morphological and biochemical characteristics of the isolated LABs are shown in Table 6. Thirteen (13) lactic acid bacteria isolates were obtained from kununzaki drink samples and were identified as Lactobacillus delbrueckii $i_{(\mathrm{a})}, L$. delbrueckii $_{(\mathrm{b}),}$ L. fermentum(a), L. delbrueckii ${ }_{(\mathrm{c})}, L$. fermentum $_{(\mathrm{b})}$, L. fermentum $_{(\mathrm{c})}$, L. fermentum $_{(\mathrm{d})}$, L. fermentum $_{(\mathrm{e})}$, L. delbrueckii ${ }_{(\mathrm{d})}$, L. delbrueckii $(\mathrm{e})$, L. plantarum, L. casei, L. delbrueckii $_{(\mathrm{f})}$. The predominant LAB is L. fermentum, the LABs identified in this study had previously been reported on by [33] and [34] in locally fermented cereal based drinks samples. Some isolates reported on were identified in this study. Kununzaki can undergo spoilage as a result of presence of some microorganisms in the drink that are involved in the fermentation process which is not deliberately halted. Studies have shown that Kununzaki drink contains lactic acid bacteria such as Lactobacillus sp, Streptococcus sp and Leuconostoc sp which could cause the spoilage of the beverage [30]. Studies conducted by [28] and [29] revealed that LABs are the predominant microorganisms involved in the fermentation of cereal-based products including kununzaki.

\section{F. Identities of Moulds Isolated from Kununzaki Samples}

Morphological characteristics of the isolated moulds are shown in Table 7. The isolated moulds were identified as Aspergillus niger and Curvularia affinis. Presence of moulds in kununzaki has been reported by [25]. Presence of these moulds in large quantity in the food drink could cause the spoilage of kununzaki beverage [29].
TABLE 7: MORPHOLOGICAL AND CULTURAL CHARACTERISTICS OF FunGaL ISOLATES FROM KUNUNZAKI

\begin{tabular}{llc}
\hline Isolate & \multicolumn{1}{c}{ Morphological Characteristics } & Identity \\
\hline & Dark moulds with rough surface, no sclerotia, \\
& flat surface, has an upright Conidiosphores that \\
terminate in a deviate swelling bearing phialides & \\
at the apex or radiating from the entire surface. & \\
& Conidiophores are smooth, hyaline or faintly \\
& brownish near the apex Apices are spherical, but \\
& often quite small. Two series of conidia-bearing \\
cells (supporting cells and phialides) are & \\
produced, but in some heads only phialides are & Aspergillus \\
present. Supporting cells are of varying lengths & niger \\
and sometimes septate. Conidia are typically & \\
spherical at maturity, often very rough or spiny, & \\
and very dark in color or with \\
conspicuous longitudinal striations. Aspergillus \\
niger is recognized by the production of \\
compact, greenish black, brownish black, \\
purplish black, or carbon black, spherical or \\
columnar spore heads. \\
Dark green on plate, septate, long conidiospores \\
Conidiophores arise singly or in groups, \\
terminally and laterally on the hyphae, also on \\
stromata when these are present. On natural \\
substrata, conidiophores are erect, simple, \\
straight, or flexuous, sometimes geniculate, Curvularia \\
septate, brown, paler near the apex, smooth, \\
thick just above the basal swelling. In culture \\
simple or loosely branched, flexuous, often \\
geniculate, septate, pale brown to brown, \\
smooth, Conidia are often curved but seldom \\
geniculate.
\end{tabular}

G. Antimicrobial Activity of LAB isolates against Selected Food-borne Pathogens

The results of the antimicrobial activity of the LAB isolates against Staphylococcus aureus and Escherichia coli are presented in Table 8, Plates $1 \mathrm{a}$ and $1 \mathrm{~b}$. The inhibitory effects of $\mathrm{LAB}$ on food borne pathogens ranged from halo zones of varying diameters ranging from $3.0 \mathrm{~mm}$ to $9.0 \mathrm{~mm}$ against Staphylococcus aureus and $1.0 \mathrm{~mm}$ to $5.0 \mathrm{~mm}$ against Escherichia coli. Lactobacillus delbrueckii (strain b) exhibited the greatest inhibition against Staphylococcus aureus while Lactobacillus fermentum exhibited the greatest inhibition against Escherichia coli. All LAB isolates except Lactobacillus casei showed inhibitory effects on Staphylococcus aureus, while Lactobacillus delbrueckii (strains a and b) and Lactobacillus fermentum showed inhibitory effects on Escherichia coli.

The antimicrobial effect of strains of Lactobacillus fermentum on Staphylococcus aureus showed varying zones of inhibition and could be because they are of different strains. The diameters of inhibition zones formed vary among the isolates regardless of the indicator bacteria. This could be attributable to different levels of antimicrobial substances secreted into Kununzaki drink by the different strains of the LAB isolates since the level of antimicrobial substances produced by probiotic bacteria has been shown to be straindependent by [35] Since Lactobacillus delbrueckii and Lactobacillus fermentum showed highest zones of inhibition against both Staphylococcus aureus and Escherichia coli, they could therefore, find application as potential probiotics in production of probiotic Kununzaki drink. 
TABLE 5: BIOCHEMICAL CHARACTERIZATION AND IDENTIFICATION OF BACTERIA ISOLATED FROM ENRICHED KUNUNZAKI DRINK

\begin{tabular}{|c|c|c|c|c|c|c|c|c|c|c|c|c|c|c|c|c|c|c|c|c|c|c|c|c|c|}
\hline \multirow[b]{2}{*}{ 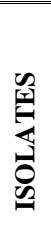 } & \multirow[b]{2}{*}{ ڤ } & \multirow[b]{2}{*}{ 芦 } & \multirow[b]{2}{*}{ 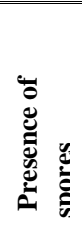 } & \multirow[b]{2}{*}{ 总 } & \multirow[b]{2}{*}{ 畩 } & \multirow[b]{2}{*}{$\frac{\varrho}{\Xi}$} & \multirow[b]{2}{*}{ 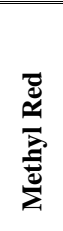 } & \multirow[b]{2}{*}{$\vec{z}$} & \multirow[b]{2}{*}{ 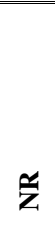 } & \multirow[b]{2}{*}{$\begin{array}{l}\bar{\Xi} \\
\tilde{z} \\
0 \\
i n \\
i\end{array}$} & \multirow[b]{2}{*}{ 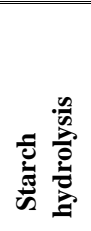 } & \multirow[b]{2}{*}{ 密总 } & \multirow[b]{2}{*}{ 莺 } & \multirow[b]{2}{*}{ 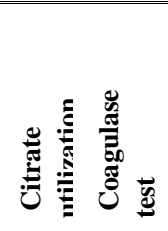 } & \multirow[b]{2}{*}{ 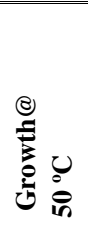 } & \multirow[b]{2}{*}{ 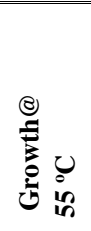 } & \multirow[b]{2}{*}{ 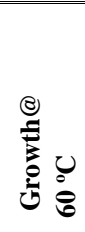 } & \multicolumn{6}{|c|}{ Sugar Fermentation } & \multirow[b]{2}{*}{ 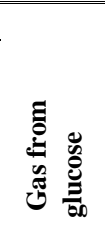 } & \multirow[b]{2}{*}{ 总 } \\
\hline & & & & & & & & & & & & & & & & & & $\underset{:}{0}$ & 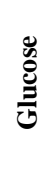 & 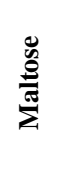 & 芯 & & 㟥 & & \\
\hline $\mathrm{A}$ & + & Rods & + & + & + & - & - & - & + & - & + & - & + & ND & - & - & - & + & + & + & - & + & - & - & Bacillus brevis $_{(\mathrm{a})}$ \\
\hline B & + & Rods & + & + & - & - & - & - & + & - & + & + & + & ND & - & - & - & + & + & - & - & + & - & - & Bacillus badius \\
\hline $\mathrm{C}$ & + & Rods & + & + & + & - & - & - & + & - & + & - & + & ND & - & - & - & + & + & - & - & + & - & - & B. brevis $_{(\mathfrak{b})}$ \\
\hline D & + & Rods & + & + & - & - & - & + & + & - & + & + & + & ND & + & - & - & + & + & - & - & + & - & - & B. polymyxa \\
\hline $\mathrm{E}$ & + & Rods & + & + & + & - & + & - & - & - & + & + & + & ND & - & - & - & + & + & - & - & + & - & - & B. macquariensi $s_{(\mathfrak{a})}$ \\
\hline $\mathrm{F}$ & + & Cocci & - & + & + & - & - & - & - & - & + & + & + & + & + & - & - & + & + & - & - & + & - & - & Staphylococcus aureus \\
\hline G & + & Cocci & - & + & + & - & - & - & - & - & + & - & - & - & + & - & - & - & - & - & - & - & - & - & Staphylococcus epidermidis \\
\hline $\mathrm{H}$ & + & Rods & + & + & + & - & - & - & + & - & + & - & - & ND & + & - & - & + & - & + & - & - & - & - & B. pantothenticus \\
\hline I & _ & Rods & - & - & - & - & - & - & - & - & + & + & + & ND & - & - & - & + & + & - & - & + & - & - & Serratia marcescens \\
\hline $\mathrm{J}$ & + & Rods & + & + & - & - & + & - & - & - & + & + & + & ND & + & - & - & + & + & + & - & - & - & - & B. macquariensis ${ }_{(\mathfrak{b})}$ \\
\hline $\mathrm{K}$ & + & Rods & + & + & + & - & + & - & - & - & + & + & + & $\mathrm{ND}$ & - & - & - & + & + & + & + & + & - & - & B. macquariensis $(\mathrm{c})$ \\
\hline
\end{tabular}

${ }^{*}=$ Note: $\mathrm{VP}=$ Voges-Proskaeur; $\mathrm{NR}=$ Nitrate reduction; $\mathrm{ND}=$ not detected.

TABLE 6: BIOCHEMICAL CHARACTERIZATION AND IDENTIFICATION OF LACTIC ACID BACTERIA ISOLATED FROM ENRICHED KUNUNZAKI DRINK

\begin{tabular}{|c|c|c|c|c|c|c|c|c|c|c|c|c|c|c|c|c|c|c|c|c|c|c|c|c|c|c|c|}
\hline \multirow[b]{2}{*}{ 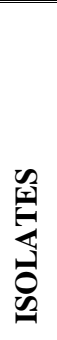 } & \multirow[b]{2}{*}{ 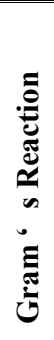 } & \multirow[b]{2}{*}{ ڤัँ } & \multirow[b]{2}{*}{ 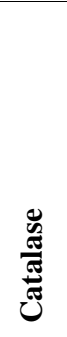 } & \multirow[b]{2}{*}{ 苞 } & \multirow[b]{2}{*}{ 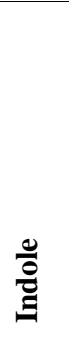 } & \multirow[b]{2}{*}{ 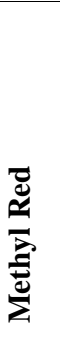 } & \multirow[b]{2}{*}{$\overrightarrow{>}$} & \multirow[b]{2}{*}{ 觉 } & \multirow[b]{2}{*}{$\begin{array}{l}\bar{\Xi} \\
\tilde{z} \\
o \\
\dot{\nabla}\end{array}$} & \multirow[b]{2}{*}{ 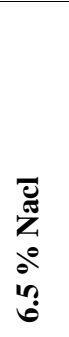 } & \multirow[b]{2}{*}{ 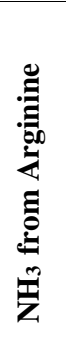 } & \multirow[b]{2}{*}{ 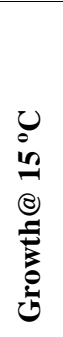 } & \multirow[b]{2}{*}{ 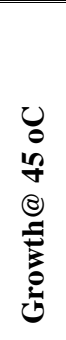 } & \multicolumn{12}{|c|}{ Sugar Fermentation } & \multirow[b]{2}{*}{ 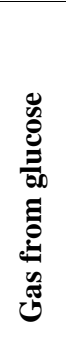 } & \multirow[b]{2}{*}{$\begin{array}{l}\stackrel{\Xi}{\Xi} \\
\stackrel{\Xi}{\Xi}\end{array}$} \\
\hline & & & & & & & & & & & & & & 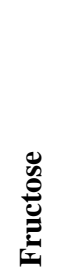 & 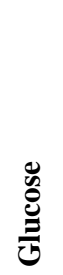 & 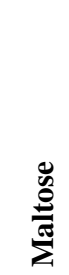 & 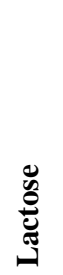 & 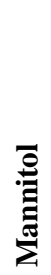 & 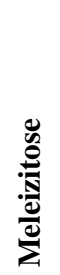 & 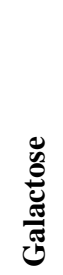 & 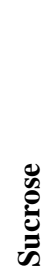 & 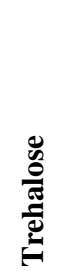 & 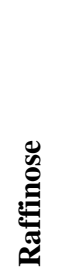 & 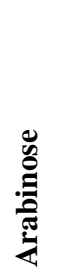 & 莺 & & \\
\hline A & + & Rods & - & - & - & + & + & + & + & + & - & - & - & + & + & + & + & - & + & + & + & + & + & + & - & - & Lactobacillus delbrueckii $_{(\mathrm{a}}$ \\
\hline B & + & Rods & - & - & - & + & - & + & + & + & - & - & - & + & + & + & + & - & + & + & + & + & + & + & - & - & Lactobacillus delbrueckii $i_{(\mathrm{b})}$ \\
\hline $\mathrm{C}$ & + & Rods & - & - & - & + & - & + & + & + & - & - & + & + & + & + & + & - & + & + & + & + & + & + & - & + & Lactobacillus fermentum $_{(\mathrm{a})}$ \\
\hline $\mathrm{D}$ & + & Rods & - & - & - & + & - & + & + & + & - & - & + & + & + & + & + & - & + & + & + & + & + & + & - & - & Lactobacillus delbrueckii $i_{(\mathrm{c})}$ \\
\hline $\mathrm{E}$ & + & Rods & - & - & - & + & - & + & + & + & - & + & + & + & + & + & + & - & + & + & + & + & + & - & - & + & Lactobacillus fermentum $_{(\mathrm{b})}$ \\
\hline $\mathrm{F}$ & + & Rods & - & - & + & + & + & + & + & + & - & - & + & + & + & + & + & - & + & + & + & + & + & + & - & + & Lactobacillus fermentum $_{(\mathrm{c})}$ \\
\hline G & + & Rods & - & - & - & + & + & + & + & + & - & - & + & + & + & + & + & - & + & + & + & + & + & + & - & + & Lactobacillus fermentum $_{(\mathrm{d})}$ \\
\hline $\mathrm{H}$ & + & Rods & - & - & - & + & + & + & + & + & - & - & + & + & + & + & + & - & + & + & + & + & + & + & - & + & Lactobacillus fermentum $_{(\mathrm{e})}$ \\
\hline I & + & Rods & - & - & - & + & - & + & + & - & - & - & - & + & + & + & + & - & + & + & + & + & + & + & - & - & Lactobacillus delbrueckii $i_{(\mathrm{d})}$ \\
\hline $\mathrm{J}$ & + & Rods & - & - & - & + & - & + & + & + & - & - & - & + & + & + & + & - & + & + & + & + & + & + & - & - & Lactobacillus delbrueckii $i_{(\mathrm{e})}$ \\
\hline K & + & Rods & - & - & - & + & - & + & - & - & - & - & - & + & + & + & + & - & + & + & + & + & + & + & - & + & Lactobacillus plantarum \\
\hline $\mathrm{L}$ & + & Rods & - & - & - & - & - & - & - & + & - & - & - & + & + & + & + & + & + & + & + & + & + & + & + & - & Lactobacillus casei \\
\hline M & + & Rods & - & - & - & - & - & + & - & + & - & - & - & + & + & + & + & - & + & + & + & + & + & + & - & - & Lactobacillus delbrueckii $i_{(\mathrm{f})}$ \\
\hline
\end{tabular}

${ }^{*}=$ Note: $\mathrm{VP}=$ Voges-Proskacur; NR $=$ Nitrate reduction. 
TABLE 8: ANTimicrobial Activity Of LAB IsOlates Against Selected FOOD-BORNE PATHOGENS

\begin{tabular}{|c|c|c|c|}
\hline \multirow{2}{*}{$\begin{array}{l}\text { Isolate } \\
\text { code }\end{array}$} & \multirow{2}{*}{$\begin{array}{l}\text { Lactic Acid } \\
\text { Bacteria }\end{array}$} & \multicolumn{2}{|c|}{ Food-borne Pathogens } \\
\hline & & $\begin{array}{c}\text { Staphylococcus } \\
\text { aureus }\end{array}$ & $\begin{array}{c}\text { Escherichia } \\
\text { coli }\end{array}$ \\
\hline A & $\begin{array}{c}\text { Lactobacillus } \\
\text { delbrueckii }\end{array}$ & $+(9.0 \mathrm{~mm})$ & $+(3.0 \mathrm{~mm})$ \\
\hline B & $\begin{array}{l}\text { Lactobacillus } \\
\text { fermentum }\end{array}$ & $+(7.0 \mathrm{~mm})$ & $+(5.0 \mathrm{~mm})$ \\
\hline $\mathrm{C}$ & $\begin{array}{c}\text { Lactobacillus } \\
\text { plantarum }\end{array}$ & $+(6.0 \mathrm{~mm})$ & $-\mathrm{ve}$ \\
\hline $\mathrm{D}$ & $\begin{array}{c}\text { Lactobacillus } \\
\text { casei }\end{array}$ & -ve & -ve \\
\hline E & $\begin{array}{c}\text { Lactobacillus } \\
\text { delbrueckii }\end{array}$ & 7.0 & -ve \\
\hline
\end{tabular}
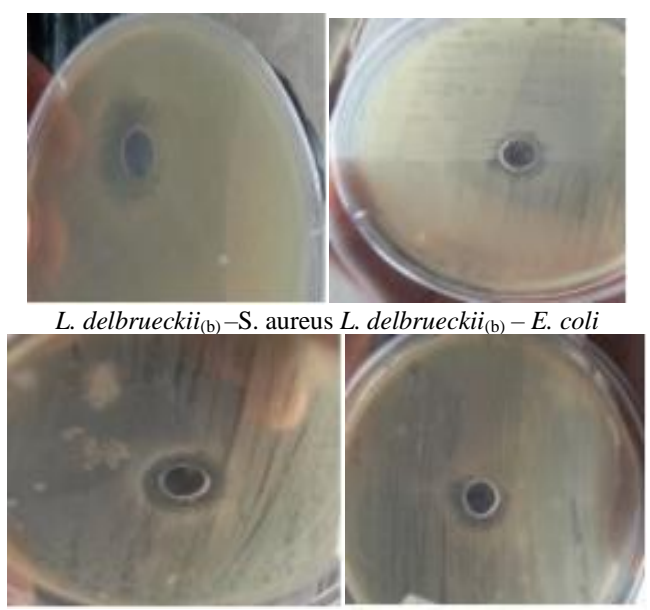

L. fermentum-S.aureus L. fermentum - E. coli

Plate 1a. Antimicrobial Activity of some LAB Isolates against Two Selected Food-borne Pathogens.

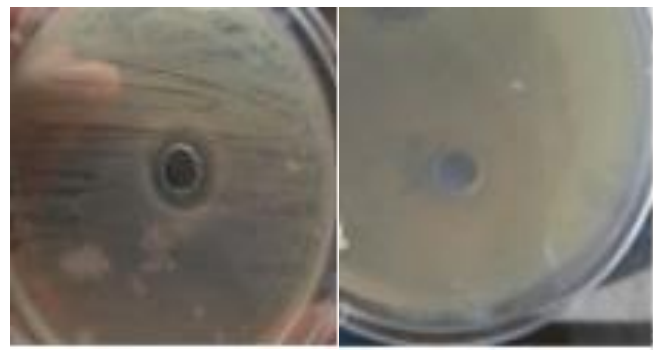

L. delbrueckii-S. aureus Lactobacillus delbrueckii- E. coli

Plate $1 \mathrm{~b}$. Antimicrobial Activity of some LAB Isolates against Two Selected Food-borne pathogen.

H. Lactic Acid Bacteria Count in Sterilized Enriched Kununzaki Drink Inoculated with Food-borne Pathogens and $L A B$, Stored at Ambient and Refrigeration Temperatures

$\mathrm{LAB}$ counts during storage at ambient and refrigeration temperatures are shown in Table 9. At week 0 , LAB counts ranged from 8.10 to $8.99 \log \mathrm{cfu} \mathrm{ml}^{-1}$ while at the end of storage, the LAB counts of samples stored at ambient temperature ranged from 8.04 to 9.30 , and 8.64 to $9.38 \log \mathrm{cfu}$ $\mathrm{ml}^{-1}$ in refrigerated samples. LAB counts of the samples stored at refrigeration temperature increased significantly $(\mathrm{p}<0.05)$; while those at ambient temperature did not follow the same pattern. This may happen if the LABs are psychrophilic as revealed in Table 6. LAB counts of enriched Kununzaki drink inoculated with Lactobacillus delbrueckii (strain b) and Escherichia coli, and enriched Kununzaki drink inoculated with Lactobacillus fermentum (strain b) and Escherichia coli, increased significantly $(\mathrm{p}<0.05)$, whereas in enriched Kununzaki samples inoculated with Lactobacillus delbrueckii (strain b) and Staphylococcus aureus, LAB counts decreased. All LABs were viable at the end of storage period in all samples.

TABLE 9: Viability Of LACTIC ACID BaCteria (LOG CFU ML -1) IN PROBIOTICATED ENRICHED KUNUNZAKI DRINK INOCULATED WITH FOODBORNE PATHOGENS, STORED AT AMBIENT AND REFRIGERATION TEMPERATURES

\begin{tabular}{|c|c|c|c|c|c|}
\hline \multirow{2}{*}{ Sample } & \multicolumn{5}{|c|}{ Storage Period (Week) } \\
\hline & $\mathbf{0}$ & 1 & 2 & 3 & 4 \\
\hline $\begin{array}{l}\text { B+EC+K } \\
\text { (Ambient) }\end{array}$ & $\begin{array}{l}8.10 \pm \\
0.02^{\mathrm{c}}\end{array}$ & $\begin{array}{l}9.03 \pm \\
0.02^{\mathrm{a}}\end{array}$ & $\begin{array}{l}8.94 \pm \\
0.02^{\mathrm{a}}\end{array}$ & $\begin{array}{l}7.63 \pm \\
0.10^{\mathrm{c}}\end{array}$ & $8.68 \pm 0.05^{\mathrm{b}}$ \\
\hline $\begin{array}{c}\mathrm{E}+\mathrm{EC}+\mathrm{K} \\
\text { (Ambient) }\end{array}$ & $\begin{array}{l}8.17 \pm \\
0.01^{\mathrm{c}}\end{array}$ & $\begin{array}{l}9.11 \pm \\
0.05^{\mathrm{b}}\end{array}$ & $\begin{array}{l}9.22 \pm \\
0.05^{\mathrm{a}}\end{array}$ & $\begin{array}{l}8.41 \pm \\
0.15^{\mathrm{c}}\end{array}$ & $9.30 \pm 0.10^{\mathrm{a}}$ \\
\hline $\begin{array}{c}\mathrm{B}+\mathrm{ST}+\mathrm{K} \\
\text { (Ambient) }\end{array}$ & $\begin{array}{c}8.99 \pm \\
0.01^{\mathrm{a}}\end{array}$ & $\begin{array}{c}8.17 \pm \\
0.40^{\mathrm{b}}\end{array}$ & $\begin{array}{c}9.06 \pm \\
0.03^{\mathrm{a}}\end{array}$ & $\begin{array}{c}7.35 \pm \\
0.07^{\mathrm{c}}\end{array}$ & $8.37 \pm 0.30^{\mathrm{b}}$ \\
\hline $\begin{array}{c}\mathrm{E}+\mathrm{ST}+\mathrm{K} \\
\text { (Ambient) }\end{array}$ & $\begin{array}{l}8.10 \pm \\
0.02^{\mathrm{c}}\end{array}$ & $\begin{array}{l}8.48 \pm \\
0.01^{\mathrm{bc}}\end{array}$ & $\begin{array}{c}9.49 \pm \\
0.34^{\mathrm{a}}\end{array}$ & $\begin{array}{l}7.28 \pm \\
0.28^{\mathrm{d}}\end{array}$ & $8.04 \pm 0.21^{\mathrm{cd}}$ \\
\hline NL (Ambient) & Nil & Nil & Nil & Nil & Nil \\
\hline $\begin{array}{c}\mathrm{B}+\mathrm{EC}+\mathrm{K} \\
\text { (Refrigerated) }\end{array}$ & $\begin{array}{l}8.10 \pm \\
0.02^{\mathrm{c}}\end{array}$ & $\begin{array}{l}8.45 \pm \\
0.04^{\mathrm{b}}\end{array}$ & $\begin{array}{c}9.10 \pm \\
0.02^{\mathrm{a}}\end{array}$ & $\begin{array}{c}9.45 \pm \\
0.21^{\mathrm{a}}\end{array}$ & $8.64 \pm 0.05^{\mathrm{b}}$ \\
\hline $\begin{array}{c}\mathrm{E}+\mathrm{EC}+\mathrm{K}- \\
\text { (Refrigerated) }\end{array}$ & $\begin{array}{l}8.17 \pm \\
0.01^{\mathrm{b}}\end{array}$ & $\begin{array}{l}9.43 \pm \\
0.05^{\mathrm{a}}\end{array}$ & $\begin{array}{c}9.57 \pm \\
0.15^{\mathrm{a}}\end{array}$ & $\begin{array}{l}8.42 \pm \\
0.01^{\mathrm{b}}\end{array}$ & $9.38 \pm 0.14^{\mathrm{a}}$ \\
\hline $\begin{array}{c}\mathrm{B}+\mathrm{ST}+\mathrm{K} \\
\text { (Refrigerated) }\end{array}$ & $\begin{array}{l}8.99 \pm \\
0.01^{\mathrm{b}}\end{array}$ & $\begin{array}{l}8.46 \pm \\
0.02^{\mathrm{bc}}\end{array}$ & $\begin{array}{l}8.49 \pm \\
0.02^{\mathrm{bc}}\end{array}$ & $\begin{array}{c}9.44 \pm \\
0.01^{\mathrm{a}}\end{array}$ & $9.31 \pm 0.07^{\mathrm{ab}}$ \\
\hline $\begin{array}{c}\mathrm{E}+\mathrm{ST}+\mathrm{K} \\
\text { (Refrigerated) }\end{array}$ & $\begin{array}{l}8.10 \pm \\
0.02^{\mathrm{c}}\end{array}$ & $\begin{array}{l}9.34 \pm \\
0.03^{\mathrm{b}}\end{array}$ & $\begin{array}{c}10.40 \pm \\
0.02^{\mathrm{a}}\end{array}$ & $\begin{array}{l}8.28 \pm \\
0.28^{\mathrm{c}}\end{array}$ & $9.11 \pm 0.05^{\mathrm{b}}$ \\
\hline $\begin{array}{c}\mathrm{NL} \\
\text { (Refrigerated) }\end{array}$ & Nil & Nil & Nil & Nil & Nil \\
\hline
\end{tabular}

Key: $\mathbf{B}+\mathbf{E C}+\mathbf{K}=$ Sterilized Enriched Kununzaki Drink Inoculated with Lactobacillus delbrueckii $_{(\mathrm{b})}$ and Escherichia coli, $\mathbf{E}+\mathbf{E}+\mathbf{K}=$ Sterilized Enriched Kununzaki Drink Inoculated with L. fermentum ${ }_{(b)}$ and Escherichia coli, $\mathbf{B}+\mathbf{S T}+\mathbf{K}=$ Sterilized Enriched Kununzaki Drink Inoculated with Lactobacillus delbrueckii $i_{\mathrm{b}}$ and Staphylococcus aureus $\mathbf{E}+\mathbf{S T}+\mathbf{K}=$ Sterilized Enriched Kununzaki Inoculated with Lactobacillus fermentum ${ }_{(\mathfrak{b})}$ and Staphylococcus aureus $\mathbf{N L}=$ Sterilized Enriched Kununzaki.

Drink with no LAB - = No growth.

I. Inhibitory Effect of LAB isolates on Escherichia coli in Sterilized Enriched Kununzaki Drink Stored at Ambient and Refrigeration Temperatures

Results of the inhibitory effect of LABs on Escherichia coli in enriched Kununzaki drink stored at ambient and refrigeration temperatures are presented in Table 10. The results revealed that there was no growth of Escherichia coli in the probioticated kununzaki drink samples at both temperatures throughout the study period. Since there was no growth in week 0 , Presence of LABs may not have been responsible for the inhibitory effect of Escherichia coli seen in this study. However, the inhibitory effect of Escherichia coli may be as a result of the presence of spices and other antimicrobial factors. Antimicrobial properties of some of the spices used in the production of kununzaki have been documented. [37] and [38] have reported on antimicrobial property of spices against Escherichia coli and other food borne pathogens. Also, the 
inhibitory effect of Escherichia coli may be as a result of low $\mathrm{pH}$ of the drink observed in this study.

TABLE 10: GROWTH OF ESCHERICHIA COLI IN PROBIOTICATED ENRICHED KUNUNZAKI DRINK STORED AT AMBIENT AND REFRIGERATION TEMPERATURES

\begin{tabular}{lllllll}
\hline \hline \multirow{2}{*}{ Sample } & \multicolumn{5}{c}{ Storage Period (Week) } \\
\cline { 2 - 7 } & 0 & 1 & 2 & 3 & 4 \\
\hline \hline
\end{tabular}

$\mathrm{B}+\mathrm{EC}+\mathrm{K}$ (Ambient)

$\mathrm{E}+\mathrm{EC}+\mathrm{K}($ Ambient $)$

$\mathrm{EC}+\mathrm{K}$ (Ambient)

$\mathrm{B}+\mathrm{EC}+\mathrm{K}$ (Refrigerated)

$\mathrm{E}+\mathrm{EC}+\mathrm{K}$ (Refrigerated)

$\mathrm{EC}+\mathrm{K}$ (Refrigerated)

Key: $\mathbf{B}+\mathbf{E C}+\mathbf{K}=$ Sterilized Enriched Kununzaki Drink Inoculated with Lactobacillus delbrueckii $i_{(\mathrm{b})}$ and Escherichia coli, E+ EC $+\mathbf{K}=$ Sterilized Enriched Kununzaki Drink Inoculated with L. fermentum $($ b) and Escherichia coli, $\mathbf{E C}+\mathbf{K}=$ Sterilized Enriched Kununzaki Drink Inoculated with Escherichia coli only, - = no growth.

\section{J. Inhibitory Effect of $L A B$ isolates on Staphylococcus} aureus in Sterilized Enriched Kununzaki Drink Stored at Ambient and Refrigeration Temperatures

Inhibitory effect of LABs on Staphylococcus aureus in enriched Kununzaki drink stored at ambient and refrigeration temperatures are presented in Table 11. At week 0, counts of Staphylococcus aureus in kununzaki were between 2.0 and 3.0 $\left(\log \mathrm{cfu} \mathrm{ml}^{-1}\right)$ in all the samples. In all the samples, there were increases with increasing storage period whether at ambient or refrigeration temperature. The count of Staphylococcus aureus was zero in all the samples at the end of storage period. This result is in agreement with the findings of [12] who observed a reduction in population of $S$. aureus in roselle juice containing Lactobacillus $s p$ after three weeks of storage.

TABLE 11: GROWTH OF STAPHYLOCOCCUS AUREUS IN PROBIOTICATED ENRICHED KUNUNZAKI DRINK STORED AT AMBIENT AND REFRIGERATION TEMPERATURES

\begin{tabular}{|c|c|c|c|c|c|}
\hline \multirow{2}{*}{ Sample } & \multicolumn{4}{|c|}{ Storage Period (Week) } & \\
\hline & $\mathbf{0}$ & 1 & 2 & 3 & \\
\hline $\begin{array}{l}\text { B+ST+K } \\
\text { (Ambient) }\end{array}$ & $3.00 \pm 0.01^{\mathrm{a}}$ & - & - & - & \\
\hline $\begin{array}{c}\mathrm{E}+\mathrm{ST}+\mathrm{K} \\
\text { (Ambient) }\end{array}$ & $2.00 \pm 0.01^{\mathrm{b}}$ & $2.00 \pm 0.01^{\mathrm{a}}$ & $2.00 \pm 0.01^{\mathrm{a}}$ & $1.00 \pm 0.00^{\mathrm{a}}$ & \\
\hline $\begin{array}{c}\mathrm{ST}+\mathrm{K} \\
\text { (Ambient) }\end{array}$ & $3.00 \pm 0.02^{\mathrm{a}}$ & - & - & - & \\
\hline $\begin{array}{c}\mathrm{B}+\mathrm{ST}+\mathrm{K} \\
\text { (Refrigerated) }\end{array}$ & $3.00 \pm 0.01^{\mathrm{a}}$ & $2.00 \pm 0.01^{\mathrm{a}}$ & - & - & 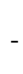 \\
\hline $\begin{array}{c}\mathrm{E}+\mathrm{ST}+\mathrm{K} \\
\text { (Refrigerated) }\end{array}$ & $2.00 \pm 0.01^{\mathrm{b}}$ & - & - & - & \\
\hline $\begin{array}{c}\mathrm{ST}+\mathrm{K} \\
\text { (Refrigerated) }\end{array}$ & $3.00 \pm 0.02^{\mathrm{a}}$ & - & - & - & \\
\hline
\end{tabular}

Values with different superscript within column are significantly different at $\mathrm{p}$ $<0.05$. $\mathbf{B}+\mathbf{S T}+\mathbf{K}=$ Sterilized Enriched Kununzaki Drink Inoculated with Lactobacillus delbrueckii $i_{(\mathfrak{b})}$ and Staphylococcus aureus, $\mathbf{E}+\mathbf{S T}+\mathbf{K}=$ Sterilized Enriched Kununzaki Drink Inoculated with Lactobacillus fermentum $m_{(\mathbf{b})}$ and Staphylococcus aureus, $\mathbf{S T}+\mathbf{K}=$ Sterilized Enriched Kununzaki Drink Inoculated with Staphylococcus aureus only,- = no growth.

\section{CONCLUSION}

Viability of Lactobacillus fermentum (strain b), was high in the enriched kununzaki drink at ambient and refrigeration temperatures for 28 days. It also exhibited high antimicrobial effect on Staphyloccus. aureus- a food-borne pathogen. This suggests that it could be used to further boost health promoting characteristic of a cheap beverage in West Africa. The drink can also be made to have consistent quality by using standardized method of production employed in this study. Lactobacillus delbrueckii (strains $\mathrm{b}$ and $\mathrm{f}$ ), were also found to be suitable candidates to probioticate kununzaki drink. It was also established that Escherichia coli could not survive in kununzaki- a possible indication of its unsuitability for proliferation of other Gram negative enteric food-borne pathogens.

\section{REFERENCES}

[1] A. M. Elmahmood, and J.H. Doughari, "Microbial quality assessment of kununzaki beverages sold in Girei town of Adamawa state, Nigeria," African Journal of Food Science, vol.1, pp. 011- 015, 2007.

[2] S. M. Wakil, O.O. Bamgbose, and E.C. Ilo, "Influence of fermentation time on the microbial profile, sensory attributes and shelf-life of " $k u n u-$ tsamia", "Advances in Food Sciences, vol. 26, no. 2, pp. 52-55, 2004.

[3] S.A. Odunfa, and S. Adeyeye, "Microbiological changes during the traditional production of ogi-baba. A West African fermented Sorghum gruel," Journal of Cereal Science, vol.3, pp. 173-180, 1985.

[4] I. Andújar, M. C. Recio, R. M. Giner, and J. L. Ríos, "Cocoa polyphenols and their potential benefits for human health," Oxidative Medicine and Cellular Longevity, pp. 23, 2012.

[5] C. G. Vinderola, and J. A. Reinheimer, "Lactic acid starter and probiotic bacteria: a comparative in-vitro study of probiotic characteristics and biological barrier resistance," Food Research International, vol. 36, no. 9-10, pp. 895-904, 2003.

[6] E. Fabian, "Influence of daily consumption of probiotic and conventional yoghurt in the plasma lipid profile in young healthy women," Annals of Nutrition and Metabolism, vol. 50, no. 4, pp. 387393, 2009.

[7] K. Kailasapathy, "Survival of free and encapsulated probiotic bacteria and their effect on the sensory properties of yoghurt," LWT-Food Science and Technology, vol. 39, pp. 1221-1227, 2006.

[8] S. Salminen, E. Isolauri, and E. Salminen, "Clinical uses of probiotics for stabilizing the gut mucosal barrier: Successful strains and future challenges," Antonie van Leeuwenhoek, vol. 70, pp. 347-358, 1996.

[9] S. V. N. Vijayendra, and R. C. Gupta, "Associative growth behavior of dahi and yoghurt starter cultures with Bifidobacterium bifidum and Lactobacillus acidophilus in buffalo skim milk," Annual Microbiology, vol. 63, pp. 461-469, 2013.

[10] C. M. Peres, C. Peres, A. Hernández-Mendoza, F. X. and Malcata, "Review on fermented plant materials as carriers and sources of potentially probiotic LAB -With an emphasis on table olives," Trends in Food Science and Technology, vol. 26, pp. 31-42, 2012.

[11] B. Vijaya B. Kumar, S. Naga Sivudu, and O. V. Reddy, "Studies on physico-chemical analysis of probioticated malted cereals with Lactobacillus casei and their possible applications," International Journal of Science, Engineering and Research, vol. 6, no. 2, pp. 95-99, 2015.

[12] A. A. Aramide, S.H. Abiose, and H.A. Adeniran, "Microbial evaluation of probiotic beverage from Roselle extract,"African Journal of Food Science, vol. 1, no.12, pp. 385-392, 2009.

[13] H.A. Adeniran, T.M. Ukeyima, and S.H. Abiose, "Microbiological assessment of probioticated ginger-based beverages," Nutrition and Food Science, vol. 40 no. 2, pp. 209-220, 2010.

[14] Olaniyi, O.I., H.A. Adeniran, and S.H. Abiose, "Antimicrobial characteristics of lactic acid bacteria in African yam bean-based drink," International Food Research Journal, vol. 26, no. 6, pp. 1733-1740, 2019. 
[15] O.A. Abidoye, K. Taiwo, and H. Adeniran, "Fortification of Kununzaki drink with cocoa powder,"African Journal of Food Science, vol. 11, no. 4, pp. 112-123, 2016.

[16] A.L.B. Penna, S. Rao-Gurram, and G.V. Barbosa-Ca'novas, "Effect of milk treatment on acidification, physicochemical characteristics, and probiotics cell counts in low fat yogurt," Milchwissenschaft, vol. 62, pp. 48-52, 2007.

[17] I.A. Adeyemi, and S. Umar, "Effect of manufacture on the quality characteristics of kununzaki a millet based beverage," Nigeria Food Journal, vol. 12, pp. 34-40, 1994.

[18] S.J. Crozier, A.G. Preston, J.W. Hurst, M.J. Payne, J. Mann, L. Hainly, and D.L. Miller, "Cocoa seeds are a super fruits. A comparative analysis of various fruits powders and products," Chemistry Central Journal, vol. 5, no.5-7, 2011.

[19] A.O. Obadina, O.B. Oyewole, and T.M. Awojobi, "Effect of steeping time of milled grains on the quality of kunnuzaki (a Nigerian beverage)," African Journal of Food Science, vol. 2, pp. 033-036, 2008.

[20] W.F. Harrigan, and M.E. McCance, Laboratory Methods in Food and Dairy Microbiology. ${ }^{\text {st }}$ Ed. London: Academic Press, 1976.

[21] W.F. Harrigan, W. "Schemes for the identification of microorganisms" in Laboratory Methods in Food Microbiology, 3rd ed. London: Academic Press, p. 253, 1998.

[22] J.I. Pitts, and A.D. Hocking, Fungi and Food Spoilage (Second Edition). New York, USA, Springer Science and Business Media, 2009.

[23] [24] N. Saidi, M. Hadadji, and B. Guessas, "Screening of Bacteriocinproducing lactic acid bacteria isolated from West African Goat's milk," Global Journal of Biotechnology and Biochemistry, vol. 6, no. 3, pp. 154-161, 2011.

[24] B.O. Omafuvbe, S.H. Abiose, and O.O. Shonukan, "Fermentation of soybean (Glycine max) for soy-daddawa production by starter cultures of Bacillus," Food Microbiology, vol. 19: pp. 561-566, 2002.

[25] C.R. Ugwuanyi, R.A. Seghosine, and T.G. Onah, "Assessment of the microbiological quality of kununzaki sold at Gariki, Enugu State, Nigeria," International Journal of Microbiological Research, vol. 6, no. 2, pp. 138-144, 2015.

[26] V.J. Umoh, S.U. Oranusi, and J.K.P .Kwaga, "The public health significance of pathogens isolated from kununzaki, sold in retail outlets in Zaria, Nigeria," Nigerian Food Journal, vol. 22, pp. 10-18, 2004.

[27] S.O. Oluwajoba, F.A. Akinyosoye, and V.O. Oyetayo, "Comparative sensory and proximate evaluation of spontaneously fermenting kununzaki made from germinated and ungerminated composite cereal grains," Food Science and Nutrition, vol. 1, no. 4, pp. 336-349, 2013.

[28] M. Kostinek, I. Specht, V.A. Edward, U. Schillinger, C. Hertel, and W.H. Holzapfel, "Diversity and technological properties of predominant lactic acid bacteria from fermented cassava used for the preparation of gari, a traditional African food," Systematic and Applied Microbiology, vol. 28, pp. 527-540, 2005.

[29] I.S. Ikpoh, J.A. Lennox, I.A. Ekpo, B.E. Agbo, E.E. Henshew, and N.S Udoekong, "Microbial quality assessment of kunu beverage locally prepared and hawked in Calabar, Cross River State, Nigeria," Global Journal of Biodiversity Science and Management, vol. 3, pp. 58-61, 2013.

[30] L. Jespersen, M. Halm, K. Kpodo, and M. Jacobsen, "Significance of yeasts and moulds occurring in maize dough fermentation for kenkey production," International Journal of Food Microbiology, vol. 24, pp. 239-248, 1994.

[31] S. Thapa, and J.P. Tamang, "Product characterization of kodo ko jaanrfermented finger millet beverage of the Himalayas" Food Microbiology, vol. 21, pp. 617-622, 2004.

[32] N.A. Olasupo, S.I. Smith, and K.A. Akinside, "Examination of microbial status of selected indigenous fermented foods in Nigeria," Journal of Food Safety, vol. 22, no. 2, pp. 85-93, 2002.

[33] S.B. Oyeleke, A.K. Faruk, O.A. Oyewole, and H.Y. Nabara, "Occurrence of lactic acid bacteria in some locally fermented food products sold in Minna markets," Nigerian Journal of Microbiology, vol. 20, no. 2, pp. 927-930, 2006.

[34] S.S.D. Mohammed, and U.J.J. Ijah, "Isolation and screening of Lactic acid bacteria from fermented milk products for bacteriocin production," Annals of Food Science and Technology, vol. 14, no. 1, pp. 122-128, 2013.

[35] C.L. Ramos, L. Thorsen, R.F. Schwan, and L. Jespersen, "Strainspecifific probiotics properties of Lactobacillus fermentum, Lactobacillus plantarum and Lactobacillus brevis isolates from
Brazilian food products," Food Microbiology, vol. 36, no. 1, pp. 22-29, 2013.

[36] A.L.F. Pereira, T.C. Maciel, and S. Rodrigues, "Probiotic beverage from cashew apple juice fermented with Lactobacillus casei," Food Research International, vol. 44, no. 5, pp. 1276-1283, 2011.

[37] M.M. Škrinjar, and N.T. Nemet, "Antimicrobial effects of Spices and herbs essential oils," Acta Periodica Technologica, vol. 40, pp. 1-220, 2009.

[38] S. Sethi, A. Dutta, L.B. Gupta, and S. Gupta, "Antimicrobial activity of spices against isolated food borne pathogens," International Journal of Pharmacognosy and Pharmaceutical Science, vol.5, pp.260-262, 2013.

Hezekiah Adekanmi ADENIRAN was born in Ilesa, Nigeria on the $19^{\text {th }}$ April, 1965, He obtained his first degree in Microbiology in 1987 from University of Ilorin, Ilorin, Nigeria; Master of Technology in Food Microbiology in 2000 from Federal University of Technology, Akure, Nigeria and $\mathrm{Ph} . \mathrm{D}$. in Food Science and Technology in 2007, Obafemi Awolowo University, Ile-Ife, Nigeria.

Before joining the service of Obafemi Awolowo University, Ile-Ife in 2003, he worked in International Breweries Plc., Ilesa, Nigeria for about eleven years as Quality Control and Research Manager from 1992 to 2003. He later joined Obafemi Awolowo University, Ile-Ife, Nigeria since 2003 where he rose from the position of Assistant Lecturer to the position of Professor. He has supervised Three Ph.D theses and eleven M.Sc. Theses. He has thirty-seven published articles in reputable national and international journals.

$\mathrm{He}$ is a member of Nigeria Institute of Food Science and Technology and Nigerian Society of Microbiology.

Damilola Mercy ADENIYI, was born on $20^{\text {th }}$ April 1990 and obtained her B.Sc. Food Science and Technology degree from Federal University of Technology, Akure, Nigeria in 2012. Thereafter she graduated with M.Sc. Food Science and Technology from Obafemi Awolowo University, Ile-Ife, Nigeria in 2017. She is a member of Nigeria Institute of Food Science and Technology.

Mrs K.A. Taiwo is a Professor of Food Engineering and Processing. She obtained her B.Sc. in Food Science and Technology, and M.Sc. and Ph.D.in Agricultural Engineering from Obafemi Awolwo University, Ile-Ife, Nigeria from 1985 and 1997.She has published over 60 publications in reputable national and international journals. 